\title{
Implementasi Praktek Pembelajaran Micro Teaching Terhadap Peningkatan Keterampilan Mengajar Mahasiswa Calon Guru Biologi
}

\author{
Fahruddin ${ }^{1}$, Hartati ${ }^{2}$ \\ Program Studi Pendidikan Biologi, STKIP Bima. Jalan PiereTendeanKel. Mande Tel. Fax (0374) \\ 42801, Bima84191, Indonesia. \\ Email: bangfenmbojo@gmail.com
}

\begin{abstract}
Abstrak
Jenis penelitian ini adalah penelitian tindakan kelas dengan rancangan penelitiannya melalui empat tahap dari setiap siklus yaitu dimulai tahap perencanaan, pelaksanaan, observasilevaluasi, dan refleksi. Penelitian ini bertujuan untuk mengetahui peningkatan keterampilan mengajar mahasiswa calon guru Biologi semester V B di STKIP Bima tahun pelajaran 2017/2018. Subyek penelitian dalah seluruh mahasiswa semester VB yang berjumlah 30 orang. Penelitian ini berlangsung selama 3 bulan yaitu bulan Agustus sampai bulan Oktober 2017. Instrumen penelitian ini adalah berupa lembar observasi keterampilan mengajar dengan dua indikator penilaian, yang terdiri dari 20 pernyataan yang di isi oleh observer selama proses pembelajaran. Indikator keberhasilan belajar berstandar pada ketecapaian tujuan pembelajaran dengan kategori baik atau sangat baik pada setiap siklus pembelajaran. Berdasarkan hasil análisis dengan menggunakan rumus persentase ketercapaian tujuan pembelajaran secara klasikal, maka proses pembelajaran siklus II mencapai peningkatan dengan 28 siswa kategori baik dan sangat baik dari 30 jumlah mahasiswa semester $V B$ dan di peroleh nilai ketercapaian tujuan pembelajaran secara klasikal sebesar 93,33\%, maka kesimpulanya bahwa hasil penelitian menunjukkan ada peningkatan keterampilan mengajar pada mahasiswa calon guru Biologi semester $V B$ melalui implementasi praktek pembelajaan micro teaching di STKIP Bima tahun pelajaran $2017 / 2018$.
\end{abstract}

Kata kunci: Praktek micro teaching, keterampilan mengajar

\section{PENDAHULUAN}

Ketercapaian kompetensi peserta didik sangat tergantung dari proses belajar mengajar yang terjadi di kelas. Peran guru sebagai fasilitator pembelajaran menjadi penting untuk diperhatikan seiring harapan terhadap peningkatan kualitas hasil belajar siswa.Agar dapat menghasilkan guru yang berkompeten, maka pembinaan terhadap mahasiswa calon guru perlu dilakukan dengan seefektif mungkin.Pembinaan tersebut meliputi pembekalan terhadap kemampuan mahasiswa calon guru dalam meningkatkan kemampuan berpikir kritis agar nantinya mahasisswa calon guru yang telah menjadi guru sesungguhnya dapat mengimplementasikan dan membimbing para peserta didik sehingga dapat meningkatkan kompetensinya khususnya pada peningkatan kemampuan berpikir tingkat tinggi (Jayanti dan Fahruddin, 2017).

Kemampuan berpikir tingkat tinggi pada mahasiswa calaon guru, akan terlihat pada kecakapannnya dalam mengajar, oleh karena itu pembinaan dan pembimbingan 
mahasiswa calon guru harus sedini mungkin mengajarkan ilmu paedegogik, sehingga akhirnya nanti mereka dapat memahami ilmu keguruannya yang dapat di implementasikan pada saat mereka melaksanakan Praktek Pengalaman Lapangan. Untuk bersinergisnya ilmu seorang calon guru yang diperoleh dari dunia akademiknya harus dipraktekkan cara mengajarnya dengan istilah micro teaching.

Pengembangan praktik micro teaching ini diarahkan untuk mendukung kompetensi calon guru yang profesional. Apalagi dengan disyahkannya Undang-undang Nomor 14 Tahun 2005 tentang Guru dan Dosen menuntut adanya kualifikasi guru berpendidikan strata satu (S1). Untuk mewujudkan guru professional yang berkualifikasi S1 tersebut maka Program Pengalaman Lapangan di bidang keguruan, khususnya PPL-1 atau micro teaching menjadi sangat penting. Micro teaching atau pengajaran mikro harus mampu meningkatkan kemampuan dan wawasan mahasiswa sebagai calon guru agar lebih siap dan tangguh dalam memecahkan berbagai masalah kependidikan.

Pembelajaran mikro merupakan metode pembelajaran atas dasar performa yang tekniknya dilakukan dengan cara melatihkan komponen-komponen kompetensi dasar mengajar (teaching skill) dalam proses pembelajaran yang disederhanakan ditinjau dari aspek kompetensi mengajar, penguasaan materi, pengelolaan peserta didik, maupun mengelola waktu. Pembelajaran mikro diarahkan dalam rangka pembentukan kompetensi guru sebagai agen pembelajaran seperti yang termuat dalam UU Nomor 14 Tahun 2005. Pembelajaran mikro juga diarahkan untuk pembentukan kompetensi berdasarkan Peraturan Pemerintah Nomor 19 Tahun 2005 tentang Standar Pendidikan Nasional, di mana dalam Bab VI pasal 3 dimuat bahwa kompetensi guru meliputi: (1) kompetensi paedagogik, (2) kompetensi kepribadian, (3) kompetensi profesional, dan (4) kompetensi sosial

Pembimbingan calon guru dalam pembelajaran mikro harus diarahkan pada pembentukan kompetensi guru sebagai agen pembelajaran sepertiu dimaksud di atas. Oleh karena itu, para guru harus memperoleh bekal yang memadai agar mampu menguasai sejumlah kompetensi tersebut, baik melalui preservice maupun inservice training. Salah satu bentuk preservice training adalah pembentukan keterampilan mengajar (teaching skill). Secara praktis, bekal keterampilan mengajar dapat dilatihkan melalui kegiatan micro teaching atau pembelajaran mikro (Moerdiyanto, 2006).

Keterampilan mengajar merupakan kompetensi kompetensi profesional guru yang cukup kompleks, karena merupakan integrasi dari berbagai kompetensi guru secara utuh 
dan menyeluruh. Ada delapan keterampilan mengajar yang berperan terhadap kualitas pembelajaran, yaitu (1) kerampilan bertanya,

(2) memneri penguatan, (3) mengadakan variasi, (4) kemampuan menjelaskan, (5) membuka dan menutup pelajaran, (6) membimbing diskusi kelompok kecil, (7) mengelola kelas, (8) mengajar kelompok kecil dan perorangan. Keterampilan mengajar itu harus dikuasai secara utuh dan terintegrasi, sehingga diperlukan latihan yang sitematis melalui micro teaching atau pembelajar mikro atau pengajaran mikro (Mulyasa, 2005). Berdasarkan latar belakang di atas, maka penulis tertarik untuk mengadakan penelitian dengan judul,” Implementasi praktek pembelajaran mikro teaching terhadap peningkatan keterampilan mengajar mahasiswa calon guru Biologi.

\section{METODE}

Penelitian ini adalah penelitian tindakan kelas (PTK). Penelitian tindakan kelas adalah penelitian yang dilakukan oleh dosen/peneliti di dalam kelas, dengan tujuan untuk memperbaiki kinerja dosen sehingga hasil keterampilan mengajar mahasiswa menjadi meningkat. Rancangan penelitian melalui empat tahap menurut Kemmis dan Mc Taggart dalam (Depdiknas, 2004) yaitu dimulai tahap perencanaan, pelaksanaan, observasi/evaluasi, dan reflesksi. Penelitian dilaksanakan pada Kampus STKIP Bima selama semester ganjil, pada subyek penelitian mahasiswa semester $\mathrm{V}$ kelas $\mathrm{B}$, yang berjumlah 30 orang pada tahun ajaran 2017/2018.

Instrumen yang digunakan adalah lembar observasi yang meliputi dua aspek, yaitu aspek keterampilan menyusun rencana pembelajaran, dan aspek keterampilan mengajar yang dilakukan oleh praktikan. Aspek keterampilan menyusun rencana pembelajaran terdiri dari 4 indikator yaitu (1) pemahaman kurikulum mata pelajaran, (2) kemampuan memilih rancangan metode dan media yang digunakan, (3) kemampuan menyusun scenario pembelajaran, dan (4) intensitas konsultasi dengan pembimbing. Instrumen keterampilan menyusun rencana pembelajaran ini dijabarkan menjadi 10 butir pertanyaan. Aspek keterampilan mengajar terdiri dari indikator yaitu (1) keterampilan melaksanakan standar operasional dan prosedur mengajar, (2) keterampilan menegakkan disiplin jadwal, (3) intensitas bimbingan, dan (4) kepuasan praktikan. Instrumen keterampilan ini dijabarkan menjadi 10 butir pertanyaan (Moerdiyono, 2006). 


\section{HASIL DAN PEMBAHASAN}

Berdasarkan hasil lembaran observasi keterampilan mengajar pada siklus I, yang dilakukan pengamatannya selama 2 bulan terhadap proses kecakapan mengajar pada setiap mahasiswa kelas V B dengan hasil praktek pembelajaran micro teaching, dan kekurangannya dibahas bersama yang dijadikan refleksi bagi penampilan selanjutnya bagi mahasiswa yang perlu perbaikan, sehingga diperoleh 19 orang mendapat kategori cukup baik dan 11 orang dikategorikan baik. Adapun hasil lembar observasi siklus I dapat terlihat pada tabel dibawah ini:

Tabel 1. Data Hasil Observasi Keterampilan Mengajar Pada Siklus I Kelas V B

\begin{tabular}{|c|c|c|c|}
\hline $\begin{array}{c}\text { Jumlah } \\
\text { siswa }\end{array}$ & $\begin{array}{c}\text { Kategori } \\
\text { cukup } \\
\text { baik }\end{array}$ & $\begin{array}{c}\text { Kategori } \\
\text { baik }\end{array}$ & $\begin{array}{c}\text { Persentase } \\
\text { klasikal }\end{array}$ \\
\hline 30 & 19 & 11 & $\begin{array}{c}63,33 \% \\
\text { Cukup Baik }\end{array}$ \\
\hline
\end{tabular}

Berdasarkan tabel 1 di atas menunjukkan hasil persentase klasikal dari 30 jumlah mahasiswa kelas V B sebesar 63,33\% dan berkategori cukup baik, tetapi yang diharapkan dalam peningkatan pembelajaran dalam penelitian ini yaitu berkategori baik atau sangat baik, dengan demikian dari hasil siklus I, perlu dilanjutkan pada siklus II dengan belajar dari hasil refleksi siklus I. Adapun beberapa kekurangan yang perlu diperbaiki pada praktek pembelajaran mikro teaching I yaitu; a) penguasaan materi yang kurang sempurna, b) memahami silabus masih kurang, c) penerapan langkah-langkah metode yang kurang, dan d) penempatan waktu yang kurang.

Proses pembelajaran padasiklus II menunjukkan hasil yang sangat memuaskan peningkatan keterampilan mengajar dari mahasiswa calon guru Biologi kelas V B, dengan persentase klasikalnya sebesar 93,33\% dari perolehan jumlah mahasiswa yang berkategori cukup baik sebanyak 2 orang, baik sebanyak 10 orang, dan berkategori sangat baik sebanyak 18 orang. Adapun hasil lembar observasi siklus II dapat dilihat pada tabel 2 dibawah ini:

Tabel 2. Data Hasil Observasi Keterampilan Mengajar pada Siklus II di kelas V B

\begin{tabular}{|c|c|c|c|c|}
\hline \multirow{2}{*}{$\begin{array}{c}\text { Jumlah } \\
\text { siswa }\end{array}$} & \multicolumn{3}{|c|}{ Kategori } & Persentase \\
baik & Baik & $\begin{array}{c}\text { Sangat } \\
\text { baik }\end{array}$ & klasikal \\
\hline 30 & 2 & 10 & 18 & $\begin{array}{c}93,33 \% \\
\text { Sangat baik }\end{array}$ \\
\hline
\end{tabular}

Berdasarkan hasil tabel 2 di atas dapat disimpulkan bahwa dari implementasi praktek pembelajaran mikro teaching yang dilakukan oleh mahasiswa calon guru biologi semester V B Tahun pelajaran 2017/2018, hasilnya dapat memuaskan dengan persentase meningkat pada siklus II sebesar 93,33\%. yang berarti proses penelitian tindakan kelas sudah tercapai standar hasil ketercapaian tujuan pembelajaran. Dari hasil pembelajaran mikro 
dapat membentuk dan mengembangkan kompetensi dasar mengajar sebagai bekal praktik mengajar di sekolah/lembaga pendidikan dalam PPL.

Menurut Moerdiyono, 2006 manfaat pembelajaran mikro yang dilatihkan secara intensif akan memberikan manfaat bagi mahasiswa, terutama dalam hal-hal sebagai berikut: (1) mahasiswa menjadi peka terhadap fenomena yang terjadi di dalam proses pembelajaran, (2) mahasiswa menjadi lebih siap untuk melakukan kegiatan praktik pembelajaran di sekolah/lembaga pendidikan, (3) mahasiswa dapat melakukan refleksi diri atas kompetensinya dalam mengajar, dan (4) mahasiswa menjadi lebih mengenal dan memahami kompetensi guru sehingga mereka dapat berpenampilan sebagai guru.

Penelitian inipun didukung oleh hasil penelitian dari Novita sari, dkk 2017 yang menyatakan bahwa (1) nilai uji $F$ menunjukkan $\mathrm{F}$ hitung $>\mathrm{F}$ tabel $(5,736>3,14)$ dengan nilai $\mathrm{p}=0,005$, sehingga $\mathrm{Ha}$ diterima dan Ho ditolak. Hal ini berarti terdapat pengaruh yang signifikan antara variabel pembelajaran micro teaching dan PPL secara simultan terhadap minat menjadi guru (2) nilai uji $\mathrm{t}$ variabel pembelajaran micro teaching adalah $\mathrm{t}$ hitung $>\mathrm{t}$ tabel $(2,009>1,99)$ dengan nilai $\mathrm{p}=0,049$ sehingga $\mathrm{Ha}$ diterima dan $\mathrm{Ho}$ ditolak. Hal ini berarti terdapat pengaruh yang signifikan variabel pembelajaran micro teaching secara parsial terhadap minat menjadi guru (3) nilai uji t variabel PPL adalah t hitung $>\mathrm{t}$ tabel $(2,157>1,99)$ dengan nilai $\mathrm{p}=0,035$ sehingga $\mathrm{Ha}$ diterima dan $\mathrm{H}$ ditolak. Hal ini berarti terdapat pengaruh yang signifikan variabel PPL secara parsial terdapat minat menjadi guru (4) koefisien determinasi sebesar 0,127 . Hal ini dapat diartikan bahwa $12,7 \%$ minat menjadi guru dipengaruhi oleh pebelajaran micro teaching dan PPL.

\section{KESIMPULAN}

Dari beberapa hasil penelitian tersebut dapat disimpulkan bahwa implementasi praktek pembelajaran mikro teaching terhadap keterampilan mengajar mahasiswa calon guru Biologi, hasilnya sangat meningkat dengan persentase 93,33\% dengan kategori sangat baik. Praktek pembelajaran micro teaching secara konsisten, mantap dan berkesinambungan, dapat meningkatan mutu lulusan Lembaga Pendidikan Tenaga Kependidikan (LPTK) mencapai standar minimal sebagai calon guru yang professional.

\section{DAFTAR PUSTAKA}

Departemen Pendidikan nasional, (2005). Peraturan Pemerintah Nomor 19 Tahun 2005 Tentang Standar Pendidikan Nasional. Jakarta: Depdiknas.

Jayanti, M.I, dan Fahruddin. 2017. Pembelajaranberbasismasalahdengan pendekatanandragogisebagai upaya 
mengoptimalkankemampuanberpikirkri tis mahasiswa calon guru biologi. Prosiding seminar nasional dan kongres HPBI.

Mulyasa, (2005). Menjadi Guru Profesional : Menciptakan Pembelajaran Kreatif dan Menyenangkan. Bandung: Remaja Rosdakarya.

Moerdiyanto. 2006. Artikel jurnal mikro teaching. FISE UNY.

Novita Sari, Trisno Martono, Sri Wahyuni 2017. pengaruh pembelajaran micro teaching dan program pengalaman lapangan (ppl) terhadap minat menjadi guru pada mahasiswa. Program Studi Pendidikan Ekonomi Fakultas Keguruan dan Ilmu Pendidikan, Universitas Sebelas Maret

Republik Indonesia, (2005). Undang-undang Nomor 14 Tahun 2005 tentang Guru danDosen. Jakarta: Depdiknas. 